\title{
Cannes 2002 Report
}

\author{
By Ron Holloway
}

Fall 2002 Issue of KINEMA

FESTIVAL DE CANNES 2002 - FILMS IN COMPETITION

VIEWED from the critical side, the $55^{\text {th }}$ Cannes International Film Festival will unfortunately be remembered by critics and professionals for its faulty jury decisions. Roman Polański's The Pianist (Poland / France / Germany), based on the memoirs of Polish concert pianist Wladislaw Szpilman, was awarded the Golden Palm, although the 150-minute Holocaust drama seemed at best contrived, laboured, and uninspired. Aki Kaurismäki's Mies vailla menneisyyttä (The Man without a Past, Finland / France / Germany), voted the Grand Prix as well as Best Actress Award to Kati Outinen, came across at least as a worthy homage to the American film noir of the postwar years. Jack Nicholson's multilayered performance as a retired "little man" from Midwest America in Alexander Payne's About Schmidt (USA) far outdistanced Olivier Gourmet's straightforward interpretation of a working-man's confrontation with a lad who had unintentionally murdered his son in Jean-Pierre and Luc Dardenne's Le Fils (The Son, Belgium / France). How could Paul Laverty be awarded Best Screenplay for Ken Loach's Sweet Sixteen (UK / Germany) when the director's whole career is based on improvisation? Even the dialect spoken by the Scottish juveniles had to be subtitled to be understood at all! And why the Cannes jury chose to overlook Alexander Sokurov's Russian Ark (Germany / Russia) -- a revolutionary moment in cinema history -- implied that there may be some truth in the oft-heard canard that scandals are found in the jury room, not on screen at a festival.

Viewed from political side, however, the very presence of a pair of Israeli and Palestinian films set the tone for an unforgettable Festival de Cannes 2002. Amos Gitai's Kedma (Israel / France) features a Palestinian actor in his 1948 account of mutually displaced people who, in word and deed, states the Israeli-Palestinian conflict today as though it was predicted yesterday. In Elia Suleiman's Yadon Ilaheya (Divine Intervention, Palestine / France / Germany / Morocco) Israeli actors play Israeli border-guard soldiers in an absurd tale of Palestinian pain that can be extended by implication to the present occupation of Jemin and Nazareth, the latter the city of Suleiman's birth. The most important film of the festival, Divine Intervention was favoured with an honorary Jury Prize and awarded the International Critics (FIPRESCI) Prize.

Two films of political conscience censured misguided government policy. Michael Moore's Bowling for Columbine (USA), a documentary competing for the Golden Palm for the first time in 46 years, is a hard-nose statement on gun-related deaths in the United States and the ongoing battle with the gun lobby in Congress. It was awarded the "Unique Prize of the 55th Anniversary of the Festival," without bothering to pinpoint what made it particularly "unique." Marco Giusti and Robert Torelli's Bella Ciao (Italy), screened in the International Week of the Critics, chronicles in no uncertain terms police brutality during the G8 summit in Genoa in July of 2001. According to the filmmakers, it may never be shown on RAI 2, the Italian station that originally commissioned the film.

One of the highlights of Un Certain Regard was Yamina Bachir-Chouikh's Rachida, a French-financed debut feature film on conditions in Algeria. Set during the worst period of terrorism in Algiers, it's the story of Rachida, a young and attractive teacher who lives and works among the underprivileged. One morning, she is challenged by a group of terrorists, one being a student of hers, for not wearing a veil to work. And when she refuses to plant a bomb in the school, she is promptly shot in the stomach. Surviving the attack, she leaves Algiers with her mother to a rural community. But since her mother is divorced and thus disgraced in the eyes of her neighbours, more trouble looms on the horizon. With elections on the horizon in Algeria when the film was screen at Cannes, Rachida was more than just a first feature by a promising Algerian woman director.

\section{COMPETITION}

Russian Ark

Either Alexander Sokurov's Russian Ark is a tour-de-force of technical achievement or a masterpiece of 
cinematic art -- probably it is both. Either way, its screening at Cannes, first as a film and then on digital, scored as a revolutionary moment in cinema history. Alone the technical side of this extraordinary film, although anticipated by such pantheon directors as Alfred Hitchcock and Max Ophüls, begs description and numbs the imagination. Produced by Jens Meuer and Judy Tossell at Egoli Tossell Film in Berlin, together with 18 coproduction partners, the film was eight years in the making, from concept to realization, the breakthrough coming when the brand new digital HD Steadicam camera allowed digital filmmaking to attain and confirm a standard of aesthetic cinematic acceptance.

Just try to fathom what it would take to cover circa 1500 metres in 35 rooms of the Hermitage Museum and the Winter Palace -- an elongated journey through nearly 400 years of Russian history, a space trip populated with 897 actors and more than 500 needed extras and assistants, the halls and corridors appropriately decorated and lighted in the best tradition of the costume epic, the spotlight on historical dramas and ballroom dancing, a visit with a blind woman painter and an overheard conversation between real-life Hermitage museum directors and art historians (Joseph Orbeli, Boris Piotrowsky, Mikhail Piotrowsky) -- all in a single shot. Indeed, how cameraman Tilman Büttner mastered this feat with his Steadicam is remarkable, to say the least.

First, the technical side. Not since the Lumière Brothers filmed The Arrival of a Train over a century ago has a one-shot film of this calibre and magnitude been attempted on this scale in motion picture history -and it's only proper that the world premiere of Russian Ark, in reference to the Hermitage as the "ark of the Russian soul," should take place in the hallowed environs of the Salle Lumière of the Cannes festival. As for the significance of the "one shot" filming principle, the best index for its creative fascination is found in the statement made by Alfred Hitchcock in his conversation interview with François Truffaut on the making of Rope (1948), a screen adaptation of a previous staged psycho-thriller.

"I undertook Rope as a stunt -- that's the only way I can describe it," said Hitchcock. "I really don't know how I came to indulge myself. The stage drama was played out in the actual time of the story. I got this crazy idea to do it in a single shot." Since cassettes in a movie camera lasts ten minutes, Hitchcock resolved the technical problem by having a figure in the drama pass before the camera to darken the image and thus allow for a second camera to continue shooting within the same time frame. One should note, too, that since the average shot lasts between 5 and 15 seconds, a 100-minute feature film could reach as much as 1,000 shots. In the case of Hitchcock's The Birds, for instance, the total number of shots soared to almost 1,500!

Now, the aesthetical side of Russian Ark. It's a "moving picture" in the purest sense of the term: a 96-minute, non-stop journey through the Hermitage Museum and the Winter Palace in St. Petersburg shot in one take on the 23rd of December 2001. As for the story, we follow a French diplomat from the 18th century, the Marquis de Custine (1790-1857), played by Sergei Dreiden, as he embarks on a journey through time to discuss art and history in a cavalier manner with a Russian acquaintance -- Alexander Sokurov himself offcamera. Along the way they, and we, encounter the royal entourages of Peter the Great (Maxim Sergeyev), Catherine the Great (Maria Kuznetsova), Tsar Nicholas I (Yuri Shurin), Tsar Nicholas II and his family at a gathering at the dinner table, these staged events capped by a full-fledged ballroom party right out of 1904 under the baton of orchestral conductor Valery Gergiev. It ends on a bravura note: the filming of the exit of a thousand or more down the staircase of the Winter Palace and back out into the wintery streets.

The premiere of Russian Ark was celebrated at Cannes with back-to-back cinematic and digital projection -- another first in the history of the festival.

\section{Yadon Ilaheya (Divine Intervention)}

Previously, Palestinian director Elia Suleiman had co-directed with Amos Gitai a feature-length documentary titled War and Peace in Vesoul (1997), about the troubled peace initiative launched by Yitzhak Rabin, Shimon Peres, and Yasir Arafat, the joint Nobel Peace Prize winners in 1994. One of Amos Gitai's favourite actors is a Palestinian: Yussef Abu Warda, who plays the Palestinian farmer driven from his village in 1948 by the Palmach, an Israeli underground army unit, in a key scene in Kedma. Place Gitai's Kedma and Suleiman's Divine Intervention side by side, and you have what may be interpreted as a joint film-political statement. More accurately, these are films that speak for the sane and rational in a conflict that is currently escalating into the madness of blatant terror and brute force. 
Who is Elia Suleiman? Born in Nazareth in 1960, he was invited to New York in 1981-83 to do research at museums and art institutions while serving as a guest lecturer at assorted American universities. Later, he made two documentaries in the United States: Introduction to the End of an Argument (1992), awarded as an experimental documentary, and Homage by Assassination (1993), recipient of a Rockefeller Award. He has received grants from the Ford Foundation and the Rockefeller Foundation.

Returning to Jerusalem in 1994, with a commission from the European Community to found a Film and Media Department at Bir Zeit University, he made his first feature film, Chronicle of a Disappearance (1996), an open statement about conditions in Palestine, was awarded Best Debut Feature Prize at the 1996 Venice festival. This was followed by two short films, The Arab Dream (1998) and Cyber Palestine (2000), the latter presented in the Directors Fortnight at the 2001 Cannes festival. It helped pave the way for Divine Intervention, his second feature film that's invited to compete at this year's Cannes festival.

An autobiographical tale, it features the director himself in a family drama and love story that spotlights three main characters: Elia Suleiman, the woman he loves (Manal Khader), and his father (Nayef Fahoum Daher). The scene shifts between Jerusalem, where Elia is staying, and Ramallah, where the woman is living, with scenes added that capture the current turmoil in Nazareth as well. Elia, while caring for his ailing father, is trying his best to keep his love life on track. But she, a Palestinian, is barred from crossing the Israeli army checkpoint between the two cities because of the heated political situation. So the lovers' intimate moments take place in a deserted lot beside the checkpoint ... an absurd, Tati-esque situation that defines the Israeli occupation of Palestinian territory in painfully explicit human terms. To say more is to give away a rib-tickling ending that takes the viewer completely by surprise.

"A chronicle of love and pain," says Elia Suleiman about Divine Intervention. It also happens to be a timely, salient film statement on the Arab-Israeli conflict today -- made in Palestine.

\section{Kedma}

"I wanted to make a film about the 'displaced' of 1948," Amos Gitai stated in his interview about the making of Kedma -- adding that the term "displaced" refers to both "the Holocaust survivors of Europe displaced in Israel and the Palestinians displaced by the Israelis." In another frank statement he pinpoints the film's importance for the present: "The conflict tearing us apart today had its source in the events of 1948." And in a third personal statement he goes right to the heart of the matter by underscoring "it's the history of people which interests me" -- thus Kedma is not just a timely political statement, but also it throws needed light on the current Israeli-Palestinian conflict.

Yet another reason why Kedma is a key event at this year's Cannes festival is the presence of a counterpart Palestinian film in the competition: Elia Suleiman's Intervention Divine. This hardly seems a coincidence. In fact, five years ago, Gitai codirected with Suleiman the feature-length War and Peace in Vesoul (1997), a documentary with improvised fiction scenes about the troubled peace initiative launched by Rabin and Arafat, the joint Nobel Peace Prize winners.

As for Kedma, the title (meaning "Toward the Orient") refers to the name of a rusty old cargo freighter that reached Palestine on 7 May 1948 and was loaded with immigrant survivors of the Holocaust. Just as the Jews disembarked on the beach, to be welcomed there by the Palmach (underground Jewish defence forces), British soldiers positioned in the hills tried to stop the unauthorized landing. In the course of the confusion on the beach, some immigrants were captured and detained, to be sent back to Europe, while others managed to escape and flee into the nearby hills.

Shortly thereafter, on May 14, the British left Palestine Then, on May 15, Ben Gurion proclaimed the independence of the State of Israel -- upon which neighbouring Arab nations invaded the country to start the first Israeli-Arab war. The war began with the Battle of Latrun to gain control of the road to Jerusalem. "The battle for this road was the centre of the war of 1948," says Gitai. "As soon as they got off the boat, the immigrants were sent to the battlefield. Some were killed less than three days after their arrival. Their names were not even known."

Kedma has an obvious link to Kippur (2000), Amos Gitai's previous Cannes entry in the competition. Just as Kippur, referring to the Yom Kippur War in October of 1973, recounted his own experiences as a member of a helicopter rescue team, so does Kedma chronicle his father's experiences in a Palmach army unit. "Right 
after Kippur, my co-writer, Marie-José Sanselme, started reading testimonies of 16- and 17-year-old boys and girls. All of them were concentration camp survivors who had arrived by boat to Palestine. They had all enlisted in the underground Jewish army, the Palmach."

As helpful as these chronicles were in reconstructing history, Gitai and Sanselme still faced the difficulty of separating truth from legend -- or "how to treat historical reality which has become legendary and disputed by two peoples." Also, when the pair began working on the project, at the end of 2000 , the second Intifada had begun. "At that time, we thought about centring the film around the battle of Latrun, told from the point of view of a Yemenite singer married to a Russian composer."

After a year of research, the pair settled for a simple structure, composed of seven key moments punctuated by songs -- from the arrival of the boat to the final monologue. The main characters, too, took shape: the couple on the boat, the Palmach officer, the Polish survivor, the Palestinian farmer -- played by Arab-Israeli actor Yussef Abu Warda ("I think he's the best actor in Israel" -- Gitai). Most significant of all, the literature of the period, both in Hebrew and in Arab, became an inspiration as well as a source of documentation. "I wanted to rediscover the emotional density of works by Haim Azaz or by Tawfik Zayad, a Palestinian poet." From that point on, the screenplay didn't need any more changes, save for what was offered by the actors and the location shooting.

Kedma was shot in five weeks, from 20 December 2001 to 25 January 2002 on locations near Beit Govrin in the Negev desert in the south of Israel. "When I shoot, I'm looking to hit a nerve," said Amos Gitai. But the creative process only begins there. Then, "by working day and night on editing and postproduction, sometimes to the limit of exhaustion, being always on the edge, I could paradoxically come to a sort of purification and reach the simplest possible expression."

\section{Ten}

Four years ago, at the 1998 Cannes festival, word went out that Abbas Kiarostami's The Taste of Cherry would be presented in the competition as an official Iranian entry. Then, just as the catalogue was about to go to print, the film was suddenly withdrawn from the competition for unknown reasons. However, on the first day of the festival, The Taste of Cherry was back in competition again -- along with the news that the director will attend after all. Although hardly a political theme, yet one that challenged moral positions in Iran since it told the story of a man seeking a companion to help him commit suicide, The Taste of Cherry was given a special-event launch at the festival by Gilles Jacob to keynote its importance.

The most popular and best known among several talented Iranian filmmakers, Abbas Kiarostami has the distinct honour of seeing his films invited to well over 500 film festivals over the past decade. And, nearly always, his films have debuted at Cannes: And Life Goes On (1992), Through the Olive Trees (1994), The Taste of Cherry, (1998), and ABC Africa, his documentary on the AIDS crisis in Africa. To date, he has made 10 features and 13 shorts and documentaries.

As for Kiarostami's Ten, the production has been described by one Iranian critic as a "one-man movie" -for Abbas himself has controlled all aspects of the film: shooting, sound, casting, directing, and editing. Furthermore, the film has been shot with a digital camera, which in turn has opened up a new avenue of aesthetic approach in his career, one that may well determine the future of Iranian Independent Cinema. It was one of the nine digitally projected films programmed at this year's Cannes festival.

In ten separate sequences Kiarostami charts the emotional life of a singular woman, a divorced mother and psychologist, who has been forced to close her office and must thereafter meet her patients in her own car -while driving! Six of the conversations are open-ended dialogues on the status of women in today's Iranian society. The other four feature conversations with the driver's young son, a loquacious and rather stubborn lad who prefers living with his father while spending free time with his mother and grandmother. These mother-son conversations transmit more depth because one notes the pain of a family dilemma that the woman, professional in all her other conversations, is somehow unable to resolve in her own life.

In view of the film's stylistic traits, the director has forsaken the usual list of credits to define the input of his staff and closest collaborators. Instead, all are listed together without the corresponding title of creative responsibility. Ten is a coproduction of Abbas Kiarostami Film and MK2, the latter a key French producer and committed supporter of the avant-guard Iranian director. 


\section{Principio da incerteza (The Principle of Uncertainty)}

He did a very good imitation of Charlie Chaplin's tramp in Wim Wenders's Lisbon Story (1993). His first and last documentary paid tribute to the city of his birth: Douro, Faina Flubia (1931) and Oporto of My Childhood (2001). At 94 years young, Portuguese master Mañoel de Oliveira is still going strong as a director of ironic, rather enigmatic, feature films. And for the past eight years he has been regularly invited to show a film in the official program at Cannes: The Convent (1995), Voyage to the End of the World (1997), Disquiet (1998), The Letter (1999), I'm Going Home (2001), and now The Principle of Uncertainty.

One reason for Oliveira's creative resilience as a filmmaker, to say nothing of his continuing perseverance on the festival scene, is his easy hand with actors, newcomers as well as veterans. Marcello Mastroianni's final moving appearance on the screen was in Oliveira's Voyage to the Beginning of the World (1997). Another Oliveira regular is John Malkovich, who starred in The Convent (1995) and did a cameo in I'm Going Home (2001) -- in which Michel Piccoli, recognized by some in that film as Oliveira's alter ego, is a stage actor who has played all the major roles in a long and fruitful career.

Some of the Portuguese master's films seemed to be triggered by the one that went before it. Take a close look at I'm Going Home, and you will see a young actress, Leonor Baldaque, auditioning for the role of Miranda in Shakespeare's The Tempest. Baldaque was also in Oliveira's Disquiet (1998) and makes an appearance in the Porto documentary on his childhood. In The Principle of Uncertainty she plays the lead in a fascinating pawn game stylized along the lines of a suspense thriller.

According to the Cannes catalogue, The Principle of Uncertainty is based on a novel by Agustina Bessa-Luis, The Jewel of the Family, although Oliveira himself now feels there's little or no relation to the literary source. The story of two youths who grew up together in a family household -- the wealthy António Clara and the poor Bleu Bull (Ricardo Trepa), the son of a family servant -- both shared everything together, including adolescent games of romance. When they fall in love with the same woman, Camilla (Leonor Baldaque), a beautiful creature and elusive blithe spirit, it's Antonio who wins her hand, to the bitter disappointment of his rival. Antonio, meanwhile, continues his affair with his mistress Vanessa (played by Leonor Silveira, another Oliveira muse), a woman of the world who is running an establishment for the well-to-do.

A melodrama with an added twist, the story moves quickly to a ménage à quatre situation, when Vanessa, jealous of Camilla, is suspected of having murdered her husband Antonio -- for which Bleu Bull has already gone to jail as the primary suspect. How this crime caper gets sorted out makes for half the pleasure of viewing The Principle of Uncertainty, for Oliveira doesn't give much away in the end -- as the film's title hints. The other half is watching the subtle changes in the characters themselves. Camilla shifts from an angelic innocent to someone entirely of a different ilk when she's interrogated by a police inspector, who in turn is on the make himself.

The Principle of Uncertainty is vintage Oliveira, a film spiced with irony and amusing twists. For the Oliveira neophyte some of the film's nuances may be difficult to fathom, much less explain, since even the genres are all mixed up. That all adds to, or abstracts from, the "the principle of uncertainty."

Marie-Jo et ses 2 amours (Marie-Jo and Her 2 Lovers)

A genuine auteur, whose early films were rarely noted beyond the borders of France, Robert Guédiguian became an international name almost overnight when his Marius et Jeannette was invited to the Un Certain Regard section at the 1997 Cannes festival, was later awarded a César, and went on from there to play the festival circuit. Another breakthrough came when Guédiguian was honoured with a 10-film retrospective tribute at the 1999 Valladolid International Film Festival, for which an insightful monograph by critic Esteve Riambeau was issued by the festival under the enigmatic subtitle "Grand Illusions". This, in turn, led to a FIPRESCI (International Critics) Prize for La Ville est tranquille (The Town Is Quiet) (2000) at last year's European Film Awards. Now, perhaps better late than never, he is competing at Cannes with his eleventh feature film, Marie-Jo et ses 2 amours (Marie-Jo and Her 2 Lovers), considered by his admirers to be his best film.

Born 1953 in the Estaque district of Marseilles, a favourite haunt of Cézanne and the Impressionists at the turn of the century, Robert Guédiguian's origins are typically foreign for this working-man's quarter of the port city. His father, who worked the docks, is Armenian, his mother German. From his mother he learned a 
respect for language and a love for literature. "At 17, I used to read Marx during the day, but every evening I'd find The Sorrows of Young Werther on my bedside table."

Goethe wasn't his only passion. A close look at his own professional career -- first as writer and screenwriter, then as filmmaker, stage director, and independent producer -- shows a literary preference for Keyserling, Brecht and Baldwin, in cinema for Renoir, Duvivier and Pasolini. Often, Guédiguian quotes directly from favourite inspirational sources in his films. His A la place du coeur (Where the Heart Is) (1998) is a screen adaptation of James Baldwin's If Beale Street Could Talk, substituting Marseilles for Harlem and Sarajevo for Puerto Rico. And A l'attaque! (Charge!) (2000), a story of two screenwriters reworking a plot visually on the screen, is a remake of Julien Duvivier's La fête à Henriette (1952).

One of five independent producers associated with AGAT Films \& Co, Robert Guédiguian exercises the privilege of making films with the same relatively unknown actors and crew. Ariane Ascaride, in particular, is nearly always paired with Gérard Meylan or Jean-Pierre Darroussin. His closest collaborators are coscreenwriter Jean-Louis Milesi and film editor Bernard Sasia. And the so-called "Estaque tales" are always set in the same proletarian district of Marseilles and with the same love and understanding for the poor. Even when the teenaged daughter in Marius et Jeannette leaves for Paris to study journalism, it's stated in the closing segment that one of her first articles cites how "Cézanne paintings of the poor of Estaque end up on rich people's walls."

Over the past 22 years, Ariane Ascaride has played the lead role in eleven feature films, and he recently directed her in a theatre production of Evelyne Pieiller's Le grand théâtre at the Théâtre National de Chaillot in Paris. "We've grown up together," he comments in passing. "The settings, too, have changed accordingly. My first film took place opposite a busy cement plant. My seventh showed its demolition. And in my eleventh film the pine forest has recovered its rights over the old site."

To a certain extent, Marie-Jo et ses 2 amours is a throwback to Robert Guédiguian's first feature film, Dernier été (Last Summer) (1980), awarded the Prix George Sadoul in 1981. Both films feature Ariane Ascaride, Gérard Meylan, and Jean-Pierre Darroussin as the leads in a tale of pain and hardship. In Marie-Jo and Her 2 Lovers Marie-Jo (Ariane Ascaride) is still very much in love with her husband Daniel (Jean-Pierre Darroussin), a construction worker, but she is also emotionally and physically attached to her lover Marco (Gérard Meylan), a pilot for incoming cargo ships in the Marseilles harbour.

Whenever Marie-Jo goes off to stay with Marco, Daniel suspects the truth yet waits patiently in pain for her return. Aware also that two loves are impossible to balance, Marie-Jo decides to bare her secret to husband and daughter -- and face the consequences, come what may. But when Daniel is asked to accept her two loves, he finds himself lacking the necessary courage and understanding. When fate plays a hand in the game as well, the melodrama runs its course to tragedy.

\section{L'Adversaire (The Adversary)}

Born 1946 in Algeria, French actress-screenwriter-director Nicole Garcia is primarily known to fans and admirers as an actress. Having played varied roles in over 50 films and tv-series dating back to the late 1960s, she has worked for some of the biggest names in French cinema -- including Resnais, Lelouch, and Tavernier. Unusually, she's also a genuine auteur -- the writer-director of five feature films made over the past 15 years: 15 août (August 15) (1986), Un week-end sur deux (Every Other Weekend, 1990), Le fils préféré (The Favourite Son, 1994), and Place Vendôme (1998). Now, two years after her stint as a jury member at Cannes, comes L'Adversaire (The Adversary), invited to compete at this year's Cannes festival.

The Adversary, the screen adaptation of a book by Emmanuel Carrère, is about a criminal file on multiple murders that took place nearly ten years ago, on 9 January 1993. Jean-Claude Romand killed his wife, children, and parents -- then tried, and failed, to kill himself. An investigation revealed the following: for the past two decades Romand had been pretending to be a doctor he never was. Not only that -- he was never professionally engaged in anything at all. Just as his well kept secret was about to be exposed, he decided to rid himself of the pain of giving an account of his past to those whose admiring respect he could not live without.

Asked in an interview why she chose to film this story, Nicole Garcia replied: "When the Romand affair came to light, I was fascinated like everyone else, by the precipitous nature of his lies, by the incredible duration of 
what he constructed -- a false life for 20 years, a little theatre of intimates: wife, children, parents, neighbours, friends. But the horror of the crime distanced me from it."

However, as an actress herself, she perceived another element in the story that needed to be told: "From the very beginning, it seemed to me that this story finds its tragic 'novelistic' dimension in the final derailment. There's something here that propels it beyond a clinical case of mythomania, beyond the realms of social drama.." Asked why she chose to film the novel instead of simply using the actual court dossier, she admitted: "I could have confined myself to examining the prosecution file, but I owed it to Emmanuel Carrère to obtain the rights to his book, since it was the vital mediation between me and the story itself. The sorrowful and genuine voice of his interpretation of the Romand case had greatly contributed to my desire to confront this character."

The Carrère "voice" in the fictionalized account of the Romand case also led to the decision to engage Daniel Auteuil to interpret the character of Jean-Claude Romand. According to Nicole Garcia, "Daniel Auteuil was my first choice -- because he is willing to take any risk, because he is one of the few French actors to bring a tragic depth to cinema. Daniel is unique. He possesses a very special quality of 'interiority', composed of familiarity and opacity. His acting is pure cinema."

\section{OUT-OF-COMPETITION}

\section{Cidade de Deus (City of God)}

New Brazilian Cinema has benefited over the past half-decade from a new government (following the impeachment of the president in 1995), a new film law that encourages both home production and international coproductions, and a national reawakening in cinema that stems from the 500th anniversary of the almost accidental discovery of Brazil by Pedro Cabral in 1500. One of the key figures in this revival is Walter Salles, the director of Central do Brasil (Central Station) (1997), the Golden Bear winner at the 1998 Berlinale, and the producer of Fernando Meirelles's Cidade de Deus (City of God), presented out-of-competition at this year's Cannes festival.

Brazilian critic Jose Carlos Avellar pinpointed the changes in his "Image Nation" essay: "The story in Central do Brasil may also be seen -- even though not so intended -- as a metaphor for the process of reinventing Brazilian cinema in the 1990s. The film passes across landscapes and through characters that made their mark on the films of the 1960s -- the Northeast, the hinterlands, the migrants, the pilgrims, the average worker from the outskirts of the big city -- following the path of a woman who, gradually, by turning into writing what is said to her, undergoes a process of resensitization." This film metaphor explored by Walter Salles can thus be taken by extension as a definition of what Brazilian cinema has become in recent years.

Another recent Brazilian film links to Fernando Meirelles's City of God just as effectively: Carlos Dieges's Orfeu (1997), a remake of Vinicius de Morales's play Orfeu de carnival, the same source used by Marcel Camus for his Orfeu negro (Black Orpheus), the Golden Palm winner at the 1959 Cannes festival. Again, we are back in the slums of Rio de Janeiro, where nothing much has changed over the past half-century. Meirelles, who studied architecture before turning to cinema to make four shorts and documentaries since the mid-1990s, has fashioned a two-hour epic on drugs and gangs, love and revenge.

His source for his City of God is Paolo Lins's Cidade de Deus, an international best-seller about life and crime in Rio's oppressive barrios and explosive streets. For the production, Fernando Meirelles and codirector Kati Lund selected 110 young non-professionals from different Rio communities, then assembled them in a workshop for eight months of rehearsals to draw upon their personal experiences before the nineweek shoot began. City of God, shot between June and August of 2001, was delivered on a budget of US\$ 3.3 million, $80 \%$ of the funds coming from 02 Films and the rest coming from foreign sales.

\section{SPECIAL SCREENINGS}

Kagami no onnatachi (Women in the Mirror)

A veteran Japanese director with 21 features to his credit, most of them on the melodramatic side, Yoshishige 
"Kiju" Yoshida stopped making films in 1988 -- and disappeared pretty much from sight for the next 14 years. However, he did on one occasion join a group of 40 international film directors to contribute a one-minute episode to Lumière et compagnie (Lumière and Company) (1995), a compilation documentary produced to celebrate the centennial year of the cinema. There were three rules to this remarkable, topsy-turvy "compagnie" series: firstly, no longer than 52 seconds; secondly, no synchronized sound, and thirdly, no more than three takes.

Born 1933, Kiju Yoshida is best known for the films he wrote and directed for the Japanese commercial market during the late 1960s: Woman of the Lake (1966), The Affair (1967), Farewell to the Summer Light (1968), and Eros Plus Massacre (1969). Others found their way as well to an American fringe market: Heroic Purgatory (1970), Coup d'état (1973), and A Promise (1986). Then, after giving up filmmaking to work in opera, Kiju Yoshida was discovered in 1990 by French director Olivier Horn designing the sets for a French stage production of a Puccini opera -- reason enough for Horn to shoot the documentary Kiju Yoshida Meets Madame Butterfly (1993).

Kiju Yoshida's set design for Kent Nagano's staging of Madame Butterfly at the Lyons Opera House is particularly interesting. Yoshida and Nagano felt that Puccini had not only crafted an exotic melodrama, but he also touched upon, in Yoshida's words, "the prototype of a universal myth." After Pinkerton's departure, Cio-Cio San stays behind in the ruins of a bombarded city as she progressively slips into madness -- "extreme loneliness unto death," as Yoshida put it.

Invited to Cannes for a Special Screening of Kagami no onnatachi (Women in the Mirror), Kiju Yoshida appears to pick up where his set design for Madame Butterfly left off. Aï Kawase (Mariko Okada), an elderly lady living in Tokyo with her grandmother (Issiki Sae), learns one day that her long-lost daughter Masako (Yoshiko Tanaka) has been found. Masako had abandoned her new-born baby 24 years ago and disappeared completely from sight. The reason, Aï discovers, was amnesia. However, since Masako still retains one name that keeps echoing in her memory, the trio -- grandmother, mother, daughter -- decide to travel to Hiroshima in an attempt to piece together the past.

\section{De l'autre côté (From the Other Side)}

Chantal Akerman, born 1950 in Bruxelles, ranks as one of the world's leading women filmmakers, equally at home in America as she is in Europe. Her first film, Saute ma ville (Blow Up My Town) (1968), was made at 18 and starred herself in a kind of letter-writing format. One leading critic of feminist cinema viewed the oft-employed epistolary style in her films as "a series of love letters to her mother". A better index of her vision and style, however, comes from an interview: "When I saw Jean-Luc Godard's Pierrot de fou, I realized that film was a language as strong as literature can be -- it's like a person talking to oneself."

Among her 30-odd films to date -- shorts, documentaries, features -- are some noteworthy contributions to both personal and feminist cinema: Jeanne Dielman, 23 quai du Commerce, 1080 Bruxelles (1975), Dis-moi (Tell Me, 1980), the semi-autobiographical Portrait d'une jeune fille de la fin des années 60 à Bruxelles (Portrait of a Young Girl at the End of the 1960s in Brussels, 1993), and The Captive (2000), a Marcel Proust adaptation.

But on more than one occasion she has also focused on American mores in documentaries of an experimental nature or within a loose avant-garde frame. Histoires d'Amerique (Stories of America) (1989) is a collection of acted-out biographical sketches from penned accounts by Jewish immigrants who settled in Manhattan. And Sud (South) (1999) is an indictment of complacency in a southern town that's tainted by racism and violence. As in most Chantal Akerman films, the borders between fiction and documentary in these two films are effectively erased. Thus, Stories of America is more theatre than cinema, and South is more a chronicle of poetic images rather than a documentary about people and places.

Chantal Akerman's De l'autre côté (From the Other Side), given a Special Screening at Cannes, seems to pick up where her South left off. In a philosophical statement that takes its impulse and inspiration from the plight of wetbacks, particularly those who try to cross the elongated border between Mexico and the United States via a trek into the blazing Arizona desert, she makes a universal case for all "poor people who risk their lives, leave everything behind in an attempt to survive, to live elsewhere. But they're not wanted elsewhere." 
In former days, Akerman contends, the illegal wetbacks had an easier time of crossing into California via a route that generally led in the direction of San Diego. But due to advance technology, the flow into California has been more or less quelled. This leaves only the mountains and deserts of Arizona for those desperate enough to try their luck. From the American standpoint, she says, "they figured that the hardships and dangers, the cold and the heat, would stop them altogether. But you can't stop someone who's hungry."

\section{UN CERTAIN REGARD}

\section{Yazgi (Fate) and Itiraf (Confession)}

Originally, the Cannes film festival had selected only one entry for the Un Certain Regard section by the talented Turkish newcomer, Zeki Demirkubuz -- his Confession. But when it became clear that Distant, the new film by the equally talented Nuri Bilge Cedylan (Clouds of May, 2000), would not be ready in time, the decision was made to take Demirkubuz's Fate as well. Furthermore, the FIPRESCI (International Critics) Jury at the 21st Istanbul International Film Festival in April had awarded Zeki Demirkubuz for both films, Fate in the international competition and Confession in the national program. The critics' decision was unusual, to say the least, but so too are these first two films in a planned cycle titled "Tales of Darkness."

As for the declarations of the FIPRESCI Jury, Fate was cited "for its cool, restrained realism and absurd humour in depicting an indifferent character adrift in a morally judgmental society." And Confession was commended "for its austere portrayal of an emotionally intense marriage torn apart by betrayal." Inspired by The Stranger, Albert Camus's novel published in 1942, Fate is the story of an educated man, an accountant in the customs office, who feels guilty without rhyme or reason for all his acts without even exploring the causes for his state of mind. "I wanted all my life to express my own feeling of guilt," says Demirkubuz, "and my hatred towards the privileged, particularly to those who are seeking privilege only."

When Musa's mother dies in the night, he feels no pain, although he loves her, somehow welcoming the relief the loss brings. The same attitude is maintained when he marries, the more so when he is falsely accused of murdering the wife of his superior and their two young children. At the end of the film, however, we learn during a sharp give-and-take interrogation with an inquiring prosecutor why he has kept silent for four years in prison although he knew he was innocent. Still, hearing Musa's explanation of his existentialist attitude doesn't explain in the least his actions. In this regard, Musa shares the same philosophical view of the universe as Meursault in The Stranger -- namely, he exercises a total indifference to everything in existence except the physical sensations of the moment. Thus, a tale of darkness that blots out the soul.

In Confession Harun, a wealthy and successful engineer, knows that his wife has betrayed him, yet he refuses to believe the evidence because he is afraid of losing her. However, when the pain become unbearable, he decides to confront her in a showdown, a night of bitter accusations and counter-accusations. He wants his wife to "confess" in hopes that the truth will clear his own conscience. Instead, just the opposite happens -a dark secret in his own life surfaces to drive him to a confession of his own.

"It's not much of a drawback to live without the knowledge of who we are and what we are living for, without being at least curious of the truth," Demirkubuz said. "We can even say that this may prove to be good for people of our day. For, on the other hand, the opposite has many drawbacks."

Altogether, Zeki Demirkubuz plans to make five such "nihilistic" (in the searing, searching, philosophical sense promulgated by Marcel Camus in his writings) Tales of Darkness on such "empty obsessions" as evil and hopelessness in the world. Since he wrote, produced, directed, photographed, and edited Confession with a small team to assist him, in addition to shooting two films in one year, we can take this auteur at his word. It will be interesting to see in which direction the next three lead us, for not since the "tales of moral unrest" by the late Krzysztof Kieślowski has a director challenged his audience with such provoking questions on the very meaning of existence.

Who is Zeki Demirkubuz? Born 1964, he graduated from the Communications Department at Istanbul University, worked as an assistant to veteran Turkish director Zeki Ökten, and made his first feature, Block $C$, in 1994. His next two films, Innocence (1997) and The Third Page (1999), were awarded several prizes and thrust him to the forefront of the "new generation" of young Turkish directors. 


\section{Avazhayé Sarzaminé Madariyam (The Songs of My Motherland)}

Two years ago, Bahman Ghobadi's A Time for Drunken Horses (2000), a first feature film, contended for Caméra d'Or honours in the Directors' Fortnight and was awarded a share of the FIPRESCI (International Critics) Prize. This year, he is serving on the jury for the Caméra d'Or, while his The Songs of My Homeland is programmed in Un Certain Regard. An all-around talent on the Iranian film scene, Bahman Ghobadi was born 1969 in Bané in northeast Iran -- so-called Iranian Kurdistan -- assisted Abbas Kiarostami on The Wind Will Carry Us (Venice competition entry in 1999) and could be seen as an actor in Samira Makhmalbaf's Blackboards (Cannes competition entry in 2000). In fact, Bahman Ghobadi played the lead role in Blackboards -- the teacher Reeboir, who wanders across mountainous paths with a blackboard on his back to attract students to attend makeshift classes and learn to read and write. Moreover, A Time for Drunken Horses and Blackboards were both shot in Iranian Kurdistan with its austere landscape, impoverished people, and politically sensitive cultural issues.

Bahman Ghobadi began making short films at 26, joining a group of amateur filmmakers after working for a time in radio. All his films are socially oriented with an eye for the human and the personal: That Man Has Arrived (1995), Again Rain with Song (1995), Dang (1996), Part of the Notebook (1996), God's Fish (1996), Like Mother (1996), The Reception (1996), To Live in a Fog (1998), and Melodies of a Girl from the Steppes (1998). The best known of these, To Live in a Fog, was awarded the Special Jury Prize at the Clermont-Ferrand Short Film Festival. Along the way, the actor-director formed his own production company, Bahman Ghobadi Films, to write, direct, and produce A Time for Drunken Horses and now The Songs of My Motherland -- aka The Songs of My Homeland.

Once again, as in The Time of Drunken Horses, Bahman Ghobadi has returned to the harsh, wintery landscape of Iranian Kurdistan to film The Songs of My Motherland. Set during the postwar years of the Iran-Iraqi war, the effects of Iraq bombs on the Iran-Kurd people has still not worn off. Mirza (Shahab Ebrahimi), an old Iran-Kurd singer, is joined by his musician sons in the search for his ex-wife, Hanareh (Iran Ghobadi), who had gone to Iraqi Kurdistan during the war. The story of this journey of the band of musicians mirrors the fate of a people, who are always wandering, who celebrated the joy of life even while others were playing the game of war.

\section{Bemani (Stay Alive)}

Remember Dariush Mehrjui's The Cow (1969)? Programmed at the 1971 Venice festival, it was awarded the FIPRESCI (International Critics) Prize. A year later, a poll of critics voted The Cow as the best Iranian film in history up to that time. The story of a poor man in a remote destitute village, his only treasure is a cow, whom he treats as his child. One day, while away, the cow dies -- so his kindly neighbours feel obliged to dispose of the corpse and tell him that the cow had ran away. Devastated, the man begins to live in the barn instead of his hut, starts eating hay, and slowly believes that he himself is the cow.

A year after his Venice success, Dariush Mehrjui turned up in the Critics Week at the 1972 Cannes festival with other classic of Iranian cinema: The Postman (1972), a loose adaptation of Woyzeck by German dramatist Georg Büchner. It didn't take much imagination to conclude that Mehrjui was indirectly criticizing the Shah and his corrupt government in this depressing tale of a simple man browbeaten by his military superiors and betrayed by his own wife, whom he murders in a moment of insanity.

Born 1940 in Tehran, Dariush Mehrjui graduated from UCLA with a degree in philosophy. Turning to his first love, the cinema, he directed Diamond 33 in 1967, followed by The Cow (1969) and a string of successes during the 1970s: Mr. Simpleton (1970), The Postman (1972), and The Cycle (1978). Then came the Revolution and a hiatus of ten years -- until he could begin a new phase in his career with Hamoon (1989), awarded six Crystal Simorgh national prizes.

Dariush Mehrjui closed the Un Certain Regard section with Bemani (Stay Alive), a hymn to life despite the cruelties of social conditions and traditional codes of practice. Bemani (Masumeh Bakhshi), a poor young girl, is forced to marry an old man because it's required by her family. At the same time, she witnesses the agonies and self-destruction of two close girlfriends in much the same predicament. Realizing that Nasim (Shadi Heydari) and Delaram Neda Aghaylo) had no chance against paternal oppression and fraternal prejudices, she decides to rebel -- and is more than ready to suffer the consequences. 


\section{Blissfully Yours}

Thai cinema is riding a festival wave right now. When Wisit Sassamathiang's debut feature Fah talai jone (Tears of the Black Tiger) (2001) premiered last year in Un Certain Regard to strong reviews, this satire on Thai Westerns of the 1950s was immediately picked up by Miramax for American distribution. At last year's Pusan festival, the closing night attraction was Prince Chatreechalerm Yugala's Suriyothai (2001), an opulent historical epic about an heroic Thai queen of the 16th century that's down in the books as the most expensive film ever produced in Thailand. This year, Cannes audiences flocked to Apichatpong Weerasethakul's Blissfully Yours in Un Certain Regard and Penek Rattanuruang's Monrak Tansitor in the Directors Fortnight.

Born 1970 in Bangkok, Apichatpong Weerasethakul studied architecture at Khon Kaen University before transferring to the School of the Art Institute of Chicago to enrol in its filmmaking courses. Since the early 1990s, he has been making videos, shorts, and documentaries: Bullet (1993), 0116643225059 (1994), Kitchen and Bedroom (1994), and Like the Relentless Fury of the Pounding Waves (1995). Along the way, he experimented with fragmented dramatic plot structure, exploring the shifting boundaries between fiction and documentary. The, founding in 1999 his own production and distribution company, Kick the Machine, he directed Mysterious Object at Noon (2000) -- praised in the New York Times as "a film like a piece of chamber music" and voted one of the best films of the year 2000 by Film Comment and the Village Voice.

"The idea for Blissfully Yours was inspired by an incident that occurred in 1998 while I was shooting my previous film Mysterious Object at Noon at a downtown zoo in Bangkok," say Weerasethakul. "A policeman handcuffed two teenage women and threw them into a police car. I eventually learned they were illegal Burmese immigrants." But he asked himself: were these Burmese women enjoying the zoo as much as others who were present? "That question was the inspiration for Blissfully Yours, the idea of moments of happiness existing in an oppressive environment, the idea of the coexistence of lightness and darkness, of pleasure and suffering." And to put the record straight on the political issues, he adds: "I have not chosen in this story to dwell on the political issues of the Thai-Burmese border, but to focus on mundane and futile activities, which in themselves carry an underlying political message."

\section{DIRECTORS FORTNIGHT}

\section{Mon-rak Transistor (A Transistor Love Story)}

Educated along the same lines as his younger Thai contemporary, Apichatpong Weerasethakul (whose Blissfully Yours was selected for Un Certain Regard at Cannes this year), Pen-ek Ratanaruang, born 1962 in Bangkok, spent a decade in the United States at institutions of higher learning. From 1977 to 1985, he lived in New York City and studied at the Pratt Institute, majoring in Art History. Later, upon his return to Thailand, he worked as a freelance illustrator, graphic designer, and art director -- then began directing television commercials. Among his several advertising awards, both domestically and internationally, were Silver and Bronze Awards at the Cannes International Advertising Festival.

Pen-ek Ratanaruang's first feature film, Fun Bar Karaoke (1997), premiered in the Panorama section at the Berlin film festival and was awarded the Special Jury Prize at the Festival of Three Continents in France. His second feature, 6IXTYNIN9, received the FIPRESCI (International Critics) Award at the 2000 Hong Kong Film Festival.

Ratanaruang's third feature, Mon-Rak Transistor, is best described as an odyssey of self-discovery that doesn't quite fit any of the accepted genres. The focus is on the experiences that a youth from rural Thailand has in Bangkok. Until then, his lifestyle was on the simpler side of life. Now that he has achieved a measure of fame as a folk-singer, he find himself on a roller-coaster journey to fame and fortune. This, in turn, paves the way for feelings of guilt and a desire for reform and redemption. A winsome, poignant story packed with twists and surprises, Mon-Rak Transistor is remarkable for its typical Thai culture -- and folk music that's both nostalgic and wedded to a modern comic sensibility.

Farishtay Kifti Rost (Angel on the Right Shoulder)

Djamshed Usmanov (Jamshed Usmanov in English) was present at last year's Cannes festival as an actor, playing a Kazakh film director in Jol (The Road), directed by Darejan Omirbaev (Darezhan Omirbayev in 
English), a Kazakh production programmed in Un Certain Regard. His debut feature, The Flight of the Bee(f) (1998), a Tajik-South Korean production codirected by Min Buong-Hun, was one of the discoveries of the Rotterdam film festival. Min returned to Rotterdam this year to present his own first independent feature film, Let's Not Cry (2001), a Tajik-South Korean coproduction filmed in Tajikistan about a would-be musician who returns to his native village after piling up too many gambling debts in Moscow.

Born 1965, Djamshed Usmanov directed two short films -- The Man (1989) and Tchoh (1991/2000), the latter was not officially released until a decade later -- before teaming Min Buong-Hun, a graduate of the Moscow Film School (VGIK) on The Flight of the Bee. An inventive tale of a father who likes to tell stories to his son, he lets his fantasies run free in devising a way to get even with an arrogant neighbour by building an outhouse right up again the fence that borders the two properties. His next feature, The Well (2002), also explored the determination of a man who tries to realize his dreams even if the costs are high.

Now comes Angel on the Right Shoulder, a Tajik-French-Swiss coproduction programmed in Un Certain Regard. Once again, the focus is on an outsider: Hamro, a beaten-down thug who returns home to his Tajik village after ten years in Moscow and some time spent in prison to tend to his dying mother. He's also there to sell the family house in order to pay off pressing debts to neighbours and the mafia. But since his mother's last wish is to exit to her grave through a decorative double-gate, he begins to renovate the house and property. Then villagers enter the picture, and Hamro is forced to acknowledge a 10-year-old son, whom he didn't even know had existed. Mafia types also appear upon the scene, and the crooked mayor has his say. Worst of all, Hamro discovers that he's even being deceived by his own mother ...

\section{Deux (Two)}

Werner Schroeter's Deux (Two), marks the third time that the German director has collaborated with bilingual Swiss-French actress Isabelle Huppert on a production of singular interest for the cultured arthouse audience, each film making its appearance after a hiatus of five intervening years. In Malina (1991), adapted from an Ingeborg Bachman novel by Austrian writer-dramatist Elfriede Jelinek, Huppert plays the strong, rational, feminine side of a split personality (the other, weaker, masculine side was interpreted by Mathieu Carrière) in a searing psychodrama that ends on a note of fiery self-destruction -- in reference to Bachmann's own death in a fire she probably caused herself by falling asleep in bed with a lit cigarette in her hand. Malina, as is the case with Two, premiered in the Directors Fortnight at the 1991 Cannes festival

The Schroeter-Huppert pair were back together again in Poussières d'amour (Love Dust) (1996), an insightful documentary and splendid music film that featured retired female opera singers and premiered at the 1996 Locarno festival on the occasion of a Lifetime Achievement Award presented to Schroeter -- after all, although the director is still quite young, this was the seventh time that one of his films was programmed at Locarno. Filmed at the 13th-century Royaumont Abbey just north of Paris, Isabelle Huppert teamed with actress Carole Bouquet in a brace of interviews with sopranos Anita Cerquetti and Kristine Ciesinski, mezzo-sopranos Martha Mödl and Katherine Ciesinski, in an exchange of dialogue on some of the secrets of music and opera, arias and singing. Since the month-long shooting session relied heavily on spontaneity and improvisation, Schroeter relied heavily on the talents of actress Isabelle Huppert, camerawoman Elfi Mikesch, and film editor Juliane Lorenz.

Move on another five years, and you have the creative team of Schroeter-Huppert-Mikesch-Lorenz assembled once more to film Two. Again, Isabelle Huppert interprets a double role -- this time, two lonely daughters of an isolated same mother (Bulle Ogier) -- and again it's a tale of how opera and passion, rather than sex and outbursts, can knit dual personalities into a whole and perhaps avoid an impending tragedy.

\section{Un Oso Rojo (The Red Bear)}

Last year, Israel Adrián Caetano's Bolivia was not only the hit of the Critics' Week at Cannes, but also one of the most talked about films at the festival. Set in a rundown bar-restaurant in Buenos Aires, Bolivia tells the story of Freddie, the bar's cook, who has left his native Bolivia to find work in the Argentine. Struggling to keep his head above water, and hoping one day he can bring his family to Argentina and a better life, he spend 5 pesos of the 15 pesos he earns daily to phone home to La Paz. Meanwhile, he meets other outsiders sharing the same fate as himself: Rosa, a waitress from Paraguay; a gay street salesman, who comes from nearby Córdoba; and a taxi driver, who owes too many people too much money. Bolivia was later awarded the FIPRESCI (International Critics) Prize at the London festival, among an armful of other international 
awards.

Born 1969 in Montevideo, Uruguay, Israel Adrián Caetano moved at 16 to the province of Córdoba in Argentina, where he made several video shorts -- among them Visite Carlos Paz (1992), Blanco y negro (1993), and Calafate (1994) -- until a purse prize for a submitted script enabled him to shoot the short feature Cuesta Abajo (1995) on 35mm. Teaming with Bruno Stagnaro, they directed together Pizza, Birra, Faso (1997), one of the box office hits of the season. As prolific as he is creative, Caetano followed with the short feature La Expresion del deseo (1998) and the documentary Peces chicos (1999) before shooting Bolivia (2001).

This year, Caetano presented his new third feature film, Un Oso Rojo (The Red Bear), in the Director's Fortnight. The story of another outsider down on his luck, Oso (Julio Chávez) has just been released from prison on parole after serving seven years for armed robbery. His wife Natalia (Soledad Villamil) and young daughter now live with Sergio, a jobless horse-player deep into debt. Oso knows that he has to control his explosively violent temper if he is to make it at all on the outside. But since he can't find work anywhere and wants to provide for his daughter's future, Oso joins a gang to pull off another robbery -- and it backfires.

\section{Bibo Breviarium (István Bibo, Fragments)}

Some fascinating compilation-documentaries and fiction-documentaries have emerged of late from Eastern European ex-socialist countries. Drawing upon previously unavailable archival sources, their aim is to set the historical record straight -- even if it means demolishing legends and ruffling the feathers of historians. Thus, when Russian director Alexander Sokurov's Taurus -- aka Lenin's Last Days -- was programmed in the competition at last year's Cannes festival, it raised the temperatures of critics who felt their socialist ideals had been tarnished by needless frontal assault on a well kept historical secret: Lenin's last testament warning of the dangers of Stalin's power-obsessed tactics.

Also, at this year's Berlinale, the most important film of the festival was André Heller and Othmar Schmiderer's Im toten Winkel: Hitlers Sekrätarin (Blind Spot: Hitler's Secretary) (Austria), programmed in the Panorama. A straight-forward confessional account by an 82-year-old of her job six decades ago as Hitler's personal secretary, a secret that she had maintained until just recently, Blind Spot was filmed just weeks before Traudl Junge died of cancer. Her memory of some key details was so crystal-clear that one has the feeling that the historical accounts of Hitler's last days in the bunker will now have to be rewritten. Moreover, this talking-head documentary covers only 90 minutes of an eight-hour interview that leaves the viewer wondering what else "Hitler's secretary" had to say, or confess, in the footage that didn't survive the final cut.

As for Hungarian documentarist Peter Forgács's Bibo Brevarium (István Bibo, Fragments), the 13th episode in the director's ongoing Private Hungary documentation, this is a poetic, fragmentary sketch from available archival sources of the life and vision of István Bibo (born 1911), jurist and philosopher, who is regarded as one of Hungary's great political thinkers. Arrested in 1944 by the Arrow Cross fascists, Bibo was released from prison and survived the siege of Budapest while in hiding. In 1949, he was suspended from his university post. In 1956, during the Hungarian uprising, he was appointed minister in the new government, only to be arrested and imprisoned again after the communists regained control. In 1963, he was granted amnesty.

To help the viewer grasp the tone of the times, Peter Forgács has interwoven footage in István Bibo, Fragments -- aka A Bibo Reader -- on the lives of peasants and the elite bourgeois to take the pulse of the nation during these troubled times. The heroism of a man who never renounced his faith in a free Hungary and the liberty of the individual to think and act for himself is underscored on the soundtrack by Tibor Szemzo's melancholic music and Béla Bartók's modern composition.

\section{L'Imbalsamatore (The Taxidermist)}

A talented director with a portfolio of shorts, documentaries, and feature films under his arm, Matteo Garrone prefers to spend his free time painting. Born 1968 in Rome, he graduated from the Lyceum of Art in 1986, worked as an assistant cameraman for two years, and then devoted himself full time to painting. When his first short film, Silhouette (1996), was awarded, it encouraged him to found his own production company, Archimede. In 1997, he made two films back-to-back. His experimental feature film, Terra di mezzo (Middle Ground) (1997), which begins with a segment from Silhouette, was awarded the Special Jury 
Prize and the Cipputi Prize at Turin. And his documentary, Bienvenido Espirito Santo (Welcome Holy Spirit) (1997), made in collaboration with Carlo Cresto Dina, is about Pentecostal traditions and was shot in New York City.

The international breakthrough came in 1998. Together with Massimo Gaudioso and Fabio Nunziato, Matteo Garrone codirected the short film Un caso di forza maggiore (A Case of Brute Force) and shot the documentary Oreste Pipolo, fotografo di matrimoni (Oreste Pipolo, Marriage Photographer) in Naples. It was followed by his second feature film, Ospiti, awarded the Kodak Prize, a Special Mention at Angers, and Best Film at both Valencia Messina. His third feature film, Estate Romana (Roman Estate, 2000), was invited to the official selection at Venice.

As for L'Imbalsamatore (The Taxidermist), programmed at the Directors Fortnight, Matteo Garrone teamed again with screenwriter Massimo Gaudioso to sketch a tale of tormented and denied love in the lives of three people. who meet by chance. Peppino, a taxidermist, is too short. Valerio, a waiter, is too tall. And Deborah, a girl whose mouth has been surgically repaired, continually changes jobs. What brings them together are their related dreams, their secret desires, and the feeling that fate has denied them the fulfilment of a normal life. Unable to communicate with others, they are castaways who cling to the uncertainty of a love relationship that might justify their existence.

\section{Occident}

For the second year in a row, a Romanian production was invited to the Directors' Fortnight. Last year, it was Cristi Piui's Marfa si bani (Stuff and Dough); this year, it's Cristian Mungiu's Occident. Viewed together, one can surmise that Romanian cinema is currently in the midst of a national revival. Insiders credit two recent developments for the improvement. On one side, there's the National Film Centre (CFC) with its funding commission to award screenplays. On the other, there's the newly founded Transilvania International Film Festival in Cluj (aka Klausenburg) that will officially open on June 3rd, the week after Cannes closes, with its focus on national film production.

Born 1968, Cristian Mungiu's first academic interest was British and American literature. After working for a time as an English teacher, he switched over to journalism, moderated a talkshow on radio, and then produced shows for television. Returning to the Academy for Theatre and Film in Bucharest, Mungiu received his degree in Film Directing in 1998 and immediately was in demand as assistant director to Bertrand Tavernier on Le Captaine Conan and to Radu Mihaileanu on Train de vie. After directing several short films, he wrote and directed Occident, his first feature film.

"Occident gathers and intersects several stories about migration and especially about those who stay behind," says Cristian Mungiu. "The three protagonists of the film influence each other's life even without themselves knowing it." The different stories come together in a cemetery. Sorina (Anca Androne) goes there with her boyfriend Luci (Alexandru Papadopol) to visit the grave of her father in hopes of receiving a sign from heaven. Instead, a bottle falls from the sky -- right on Luci's head. While taking Luci to the hospital, Sorina meets Jerome, a Frenchman, and promptly moves in with him. In hopes of winning Sorina back, Luci takes a job as a living beer-bottle -- and meets Mihaela, who was jilted at the altar and now works as a walking telephone commercial. After this first week of absurd adventures, the film shifts gear to retell the second and third part of the same story within the space of another seven days.

\section{Matir Moina (The Clay Bird)}

A founding member of the Short Film Forum in Dhaka, Tareque Masud has spearheaded a documentary filmmaking movement and an alternative film culture in Bangladesh since the mid-1970s. Together with his American wife, Catherine Masud, they founded the Audiovision production company for the purpose of making creative documentaries that reflect the life and struggles of the people as well as the critical issues of South Asia, among them The Inner Strength, The Conversation, and Voices of Children. In 1988, he coordinated the First International Short Film Festival held in Dhaka.

Their international breakthrough came with the documentary Muktir Gaan (Song of Freedom) (1996), a critical and commercial success that won the National Award for Best Documentary and a Special Jury Prize at Film South Asia '97 in Kathmandu. Drawing upon footage previously shot by American filmmaker Lear Levin, it depicts the genocide committed by the Pakistan Army and their collaborators in 1971, when 
Bangladesh declared its independence. The same theme of the Bangladesh Liberation War was continued in Tareque and Catherine Masud's Muktir Kotha (Words of Freedom, 1999), a documentary that showed how ordinary people shared in the dream of liberation by fighting back with primitive spears, bamboo shields, and whatever means at hand.

Now comes the feature Matir Moina (The Clay Bird), produced by Catherine Masud, directed by Tareque Masud, and co-scripted by the couple. The setting is a rural community in eastern Pakistan during the late 1960s, just before the political tension boiled over into open conflict and eventual break with Pakistan. Anu, a shy boy, is sent away by his father, an orthodox Muslim, to a "Madrasah" (a strict Islamic school). Separated from his family and missing in particular the pleasure of Hindu festivities in the village, Anu struggles to adapt to the harsh monastic life at the Madrasah. Meanwhile, back in the village, the gulf of misunderstanding between his own parents grows, mirroring the increasing divide between the moderate believers and the fanatically religious in the Madrasah. The conflict intensifies -- until finally civil war breaks out.

\section{INTERNATIONAL WEEK OF THE CRITICS}

\section{Hundstage (Dog Days)}

Although the International Critics (FIPRESCI) Jury at last year's Venice festival overlooked Ulrich Seidl's Hundstage -- where it was awarded the Special Jury Prize -- a second FIPRESCI Jury made up for the oversight later at the Bratislava festival. This paved the way for Dog Days to be chosen "FIPRESCI's Revelation of the Year" -- and honoured with a Special Screening at the International Critics Week at Cannes. This marked the second time that an entry at Venice was given a critical boost again in the Critics Week at Cannes -- last year, the honour went to Christian Petzold's Die innere Sicherheit (The State I Am In, Germany), a tale of ageing terrorists of the RAF movement still on the run.

A film that tested the tolerance level of viewers at Venice due to Ulrich Seidl's known penchant for the outrageous, Dog Days offers a slice-of-life during a typical Austrian heat wave, one that usually occurs between July 24 and August 23. Some sweating bodies ache to be loved, others become more aggressive, as tempers explode into violence.

In many respects Dog Days is more of a fiction-documentary than a feature film, particularly as Seidl comes from the documentary side -- his Good News, Tierische Liebe (Animal Love) und Models have been awarded -- and likes to watch the sparks with strong non-professionals are matched with accomplished actors who can bury themselves in weird roles -- like a crazy hitchhiker, a travelling alarm salesman, a divorced couple who still share the same house together after the tragic death of their daughter, a young girl who suffers constant humiliation from her explosive boyfriend, an ageing beauty for whom sex has long replaced love.

Put them all together during some particularly boiling hot summer days, and you have a masterfully sketched, hilariously funny, emotionally draining trip into an underworld. Or, as Werner Herzog, an Ulrich Seidl admirer, out it: "Never in cinema has one looked straight into the pits of hell."

\section{Les Fils de Marie (Marie's Sons)}

"I have always been fascinated by people's personal dramas," said Carole Laure, Canada's best known international screen actress about Les fils de Marie (Marie's Sons), her first film as a director. "How do they survive the pain? How do they reconstruct their lives? I admire people who invent solutions. We live in a society that needs to recreate links -- to recreate families." And since Marie's Sons is about a mother who has lost both her husband and her 14-year-old son in a car accident, the pain goes deep -- for a time, she withdraws entirely within herself.

This loss is the entire focus of the film. "The maternal instinct is an absolute," added Laure, "because it is indestructible. It is a total gift of oneself, the ego is gone. Marie cannot accept the loss of her son. Her son was her raison d'être. Whatever the cost, she needs to re-establish that link. Her maternal love knows no limit." So what does she do? Marie places an ad in a Montréal newspaper: "Mother looking for a son looking for a mother" -- and this intricately woven human drama moves into high gear from there. For Marie is walking a thin line between sanity and madness, and the response to her ad only leads to strange encounters 
with equally troubled youths of different ages and backgrounds -- some are abused children, others cannot control their masochistic instincts, still others are obese and lonely outsiders.

Asked why she took the plunge into directing a film after having appeared on the other side of the camera in over 30 films produced in Canada and abroad, she credits the "spontaneity" in her past work with Canadian director Gilles Carle as the primary reason. "We used to work with a small crew and a low budget. Everyone participated in all kinds of ways. I could not have starting directing with a subject that was not personal. Here was a story about maternity, filiation, and loss. I could transpose it." Carole Laure coproduced and co-scripted Marie's Sons with Pascal Arnold, her cameraman on the film. "The fact that I have known and worked with Pascal for a very long time gave me the confidence I needed."

\section{Chicken Heart}

"I am quite thrilled to watch my former first assistant director blossoming into an internationally acclaimed filmmaker," said veteran Japanese director Takeshi Kitano about Hiroshi Shimizu, whose Chicken Heart has been invited to the Week of the Critics at Cannes. "It's great that his directorial career is going along steadily. His 'proud protégé of Kitano' are over. I'd like to welcome him to the dog-eat-dog filmmaking world, where we're just two guys out of a countless number. A world where only one thing counts -- keep making films that stand out."

Hiroshi Shimizu had previously assisted Japanese master Takeshi Kitano on six of his films: Sonatine (1993), Getting Any? (1995), Kids Return (1996), HanaBi (1997), Kikujiro (1999), and Brother (2000). When he directed his first feature film, Ikinai (Not to Live, 1998), it bore the imprint of his master's vision of the world. An amusing and poetic black comedy, it's about an insurance scam planned by a bunch of losers on a tour bus that's supposed to have a fatal accident on the road -- only to be foiled when a young girl gets on the bus by mistake. Instead of choosing "not to live," the nine doomed men end up putting their lives back in order. Ikinai was awarded a FIPRESCI Prize at Pusan and an Ecumenical Award at Locarno.

In Chicken Heart Shimizu picks up on the same comic theme: three down-and-out friends realize that if they don't get their lives together now, they never will. Iwano, a failed boxer now in his late twenties, earns a modest living as a "human punching bag" -- for a few minutes and at a token fee, frustrated businessmen and other passers-by can work off their anger by trying to knock "the champion" down. Maru, a hat salesman in his early thirties, is struggling to keep the family business going by selling toupés to balding men on a street corner. Sada, a dropout now into his fifties, is repairing an old boat to fulfill his dream of sailing around the world. He also harbours a heart-rending secret in his past that he won't even tell his friends about.

Each evening, the three friends meet at their favourite snack bar to talk some nonsense and try to pick up a girl. But, as luck would have, they usually get pulled into one silly affair after another. Still, the urge to straighten out their lives and to settle down with a family cannot be quieted.

\section{References}

\section{AWARDS}

\section{Official Competition}

Palme d'Or: The Pianist (Poland / France / Germany), Roman Polanski

Grand Prix: Mies Vailla Menneisyyttä (The Man Without A Past, Finland / France / Germany), Aki Kaurismäki

Best Actress: Kati Outinen in Mies Vailla Menneisyyttä (The Man Without A Past, Finland / France / Germany), Aki Kaurismäki

Best Actor: Olivier Gourmet in Le Fils (The Son, Belgium / France), Luc and Jean-Pierre Dardenne

Best Director (ex aequo): Paul Thomas Anderson, Punch Drunk Love (USA) and Im Kwon Taek, Chihwaseon (Stroke of Fire, South Korea)

Best Screenplay: Paul Laverty for Sweet Sixteen (UK / Germany), Ken Loach 
Jury Prize: Yadon Ilaheya (Divine Intervention, Palestine / France / Germany / Morocco), Elia Suleiman Unique Prize of 55th Anniversary of Festival: Bowling For Colombine (USA), Michael Moore

Short Film Awards

Palme d'Or: Eso Utan (After the Rain, Hungary), Peter Meszáros

Special Jury Prize: The Stone of Folly (Canada), Jesse Rosensweet

Jury Prize: A Very Very Silent Film (India), Manish Sha

Camera d'Or (Best Debut Feature): Bord de mer (France), Julie Lopes-Curval (Directors Fortnight)

Special Mention: Japòn (Mexico / Spain), Carlos Reygadas (Directors Fortnight)

\section{Cinéfondation Awards}

First Prize: Um sol laranjado (Four Days, Brazil), Eduardo Valente

Second Prize: K-G I nod och lust (K-G For Better or For Worse, Sweden), Jens Jonsson

Third Prize: She'elot shel po'el met (Questions about a Dead Worker, Israel), Aya Somech

International Critics (FIPRESCI) Awards:

Competition: Yadon Ilaheya (Divine Intervention, Palestine / France / Germany / Morocco), Elia Suleiman Un Certain Regard: Heremakono (Waiting for Happiness, Mauretania / France), Abdderrahmane Sissako Quinzaine des Réalisateurs: Matir Moina (The Clay Bird, (Bangladesh / France), Tareque Massud Ecumenical Award: Mies Vailla Menneisyyttä (The Man Without A Past, Finland / France / Germany), Aki Kaurismäki

Special Mention: Le Fils (The Son, Belgium / France), Luc and Jean-Pierre Dardenne

Le Prix Un Certain Regard: Sud Senaeha (Blissfully Yours), Apichatpong Weerasethakul (Thailand)

Grand Prix, Semaine Internationale de la Critique: Respiro, Emanuele Crialese (Italy / France)

\section{Author Information}

Ron HOLLOWAY (1933-2009) was an American critic, film historian, filmmaker and correspondent who adopted Europe as his home in the early fifties and spent much of his life in Berlin. He was an expert on the study of German cinema and against all odds produced, with his wife Dorothea, the journal German Film, keeping us up-to-date with the work of directors, producers and writers and the showing of German films around the world.

In 2007, Ron Holloway and his wife were awarded the Berlinale Camera Award. Ron also received the Bundesverdienstkreuz (German Cross of Merit), Polish Rings, Cannes Gold Medaille, the American Cinema Foundation Award, the Diploma for Support of Russian Cinema and an honorary award from the German Film Critics' Association.

Ron was also a valued contributor to Kinema for the past fifteen years. 